\title{
The use of the SCADA system in the monitoring and control of the performance of an autonomous hybrid power supply system using renewable energy sources
}

\author{
Grzegorz Trzmiel ${ }^{1, *}$, Maciej Łopatka ${ }^{1}$, and Dariusz Kurz ${ }^{1}$ \\ ${ }^{1}$ Poznan University of Technology, Faculty of Electrical Engineering, Institute of Electrical \\ Engineering and Electronics, St. Piotrowo 3a, 60 - 965 Poznan, Poland
}

\begin{abstract}
The paper touches upon the current issues related to the use of visualisation, control and archiving systems (SCADA) in hybrid power supply systems, based on the example of an installation that uses the energy of the sun and wind. The article contains an exemplary design of an autonomous hybrid power supply system and the SCADA system implemented in the Vijeo Citect environment. The major focus is on the presentation of the essential and the most frequently used SCADA system functionalities in terms of the monitoring and control of this type of power supply systems.
\end{abstract}

\section{Introduction}

\subsection{SCADA systems}

Production and technological processes, which take place in industrial plants require appropriate control and supervision. Frequently, the consequence of their complexity is that the use of individual controllers is insufficient, and it is necessary to apply a master system that controls the operation of many controllers. This is made possible by the SCADA systems (Supervisory Control And Data Acquisition). The supervisory applications like SCADA are used in each of the industrial branches. Owing to their use at the control station, the data collected from all the sensors and controllers is displayed, the course of the controlled process is visualised and its control is possible. An operator, being in possession of all the required information, is able to monitor and supervise the process, and also respond appropriately to any disturbance or emergency situation. The SCADA systems may also respond automatically to any changes that take place in the supervised system. The basic functions of the SCADA application include: the visualisation of the condition of an object; the process control, the signalling of disturbances and emergency states, the data collection, processing and archiving [1-4]. The systems may successfully be applied in various technical issues: in diverse optimization tasks $[19,20]$, in the modelling and simulation of phenomena which take place in many fields of electrical engineering $[21,22,26]$, in the monitoring of the

\footnotetext{
*Corresponding author: grzegorz.trzmiel@put.poznan.pl
} 
operation of modern electricity supply systems $[23,24]$ and in systems intended for the identification of the state of equipment being part of the generation and supply systems $[23,25]$.

\subsection{Hybrid power systems using renewable energy sources}

Alternative energy sources (wind and solar radiation) gain popularity because of the lack of greenhouse gas emissions into the atmosphere during their use, low variable costs (they do not require the purchase of fuel to operate) and possibility of both small-scale and large-scale implementation. Production of electricity coming from these sources, however, has a big disadvantage related to its unpredictable nature as a result of dependence on weather conditions, and the characteristics of production which does not match typical load profiles of households, or the whole power grid. The solution for this problem is the use of hybrid systems which apply the wind and solar energy to generate power supply. The combination of these two sources significantly increases the productive capacity of electricity on a weekly, monthly and yearly basis $[5,6]$. Such a system is complemented by the energy storage, which allows for the effective use of the energy coming from variable energy sources and for ensuring the appropriate power supply certainty.

\section{The project standalone installation of RES}

The renewable energy source installation which operates autonomously without any connection with the power grid, should ensure the continuous and reliable supply of good quality electricity for a single-family building. The project involves the use of the hybrid system which takes advantage of photovoltaic panels, a wind turbine, an energy storage and an emergency diesel generator, all integrated by means of a 48V DC busbar. The task of the system was to power a single-family building situated in the Wielkopolska region, occupied by a family consisting of 4 people, which consumes $3320 \mathrm{kWh}$ per year [7]. The system was configured in a manner which minimizes the influence of variable generation of electricity on its use by the recipients and ensures power supply even in the case of long periods of negative power balance.

\subsection{Electricity production}

In the case of the designed installation, the basic energy source was the wind turbine because of the electricity production profile similar to the annual load profile, with a maximum during the winter season. The SMV 3000 vertical axis wind turbine (VAWT) manufactured by RMS was used. The advantages of the vertical axis wind turbines include the stable performance, the start at low wind speed values, the lack of necessity to position the turbine in the direction of the wind, the resistance to the blows of wind and its high speed, very low noise generation and the possibility to use the turbine in built-up areas, also on building roofs. Performance at low wind speeds is very important in order to obtain the largest productive capacity of the wind turbine possible, taking into account the wind speed distribution in the Wielkopolska region. The installation comprises the turbine with a capacity of $3 \mathrm{~kW}$ and the operating range between $4 \mathrm{~m} / \mathrm{s}$ and $25 \mathrm{~m} / \mathrm{s}$. With the average wind speed of $4.5 \mathrm{~m} / \mathrm{s}$, the turbine should ensure about $3000 \mathrm{kWh}$ of electricity per year [8-11].

The turbine is complemented by photovoltaic panels made of polycrystalline silicone. They have lower efficiency than monocrystalline cells, but are characterized by a lower decrease in electricity generation during the cloudy weather, which results in a more stable performance of the source [12]. An additional advantage regarding the application of such 
panels is their low price. The project involves the use of twelve Sharp ND-RC255 photovoltaic panels with power $\mathrm{P}_{\max }$ of $255 \mathrm{~W}$, installed on the building roof and inclined at an angle of $35 \%$ [13]. With the maximum power equal to $3 \mathrm{~kW}$, under insolation conditions representative for the Wielkopolska region whose potential for production of electricity from solar radiation is $1100 \mathrm{kWh} / \mathrm{m}^{2}$, the used panels should ensure the generation of about $3000 \mathrm{kWh}$ of electricity per year [14]. In order to ensure the efficient operation of the panels, the maximum power point tracking system (MPPT) was used.

Renewable energy sources used in the project should ensure the sufficient electricity volume for a family of four in the annual balance, but the stochastic nature of the energy production based on the used sources, causes the necessity of using an energy storage that ensures power supply in the event of the negative energy balance in shorter time intervals: hourly, daily and weekly. The energy storage should be characterized by high capacity and current efficiency [22]. The energy storage which employs LG Chem RESU 6.4 EX lithiumion batteries with the capacity of $6.4 \mathrm{kWh}$ and maximum output power equal to $5 \mathrm{~kW}[15,16]$ was used in the installation.

The strong dependence of the autonomous RES installation on weather conditions may result in the lack of electricity supply to the recipient in the case of long periods of negative energy balance, despite the use of energy storages with large capacity. In order to avoid the significant oversizing of the sources and the energy storage, a diesel generator was additionally used in the project to ensure power supply for a house, if there is any energy shortage in the system, e.g. when adverse weather conditions or failures of other installation elements occur. The applied emergency solution was the Pramac diesel generator, P1 2000 series, with the maximum power of $11.07 \mathrm{~kW}$, and a possibility of electrical starting.

\subsection{Installation equipment}

The energy sources used in the installation require appropriate integration, and the generated electricity requires appropriate processing and distribution. The project involves the use of energy source interconnection by means of a 48V DC busbar. Most of the electrical devices used in households are adapted to $230 \mathrm{~V}$ AC power supply, with sinusoidal shape and frequency of $50 \mathrm{~Hz}$, which causes the necessity to use power converters that adapt the electricity parameters to the requirements of receivers. Three single-phase inverters with the constant power of $3 \mathrm{~kW}$ and instantaneous power of $6 \mathrm{~kW}$ were used in the project. They are adapted to conversion of $48 \mathrm{~V} \mathrm{DC}$ into mains voltage in the three-phase configuration [17].

In order to disconnect the energy sources, DC contactors were used. The contactors are controlled by powering the coils with a voltage of $24 \mathrm{~V}$, whose source is the PLC output.

The connection of the diesel power generator was provided in a manner which enables its integration with other energy sources owing to the use of the rectifier, as well as the by-pass of the DC circuit and inverters in the case of their failure, and direct power supply to the recipients. The disconnection of the generator takes place by means of AC contactors.

AC circuits were protected with overcurrent switches which are interoperable with auxiliary contacts that allow for the signalling of their condition in the PLC. Control of equipment and circuit power supply was ensured by means of installation contactors which are connected by the PLC.

The most important element of the installation's control system is the PLC. The WAGO controller with the modular structure was used for the purposes of the project. It is interoperable with various communication protocols and offers great flexibility owing to the possibility of using many modules for various purposes. Binary output modules for control of contactors, binary input modules which receive signals about the states of the equipment and analogue input modules which are interoperable with current transformers, signal conditioners, voltage converters used to measure the parameters of electricity and its 
consumption, and the fuel level sensor in the generator were used. The total cost of the applied equipment and energy sources would amount to about PLN 170000.

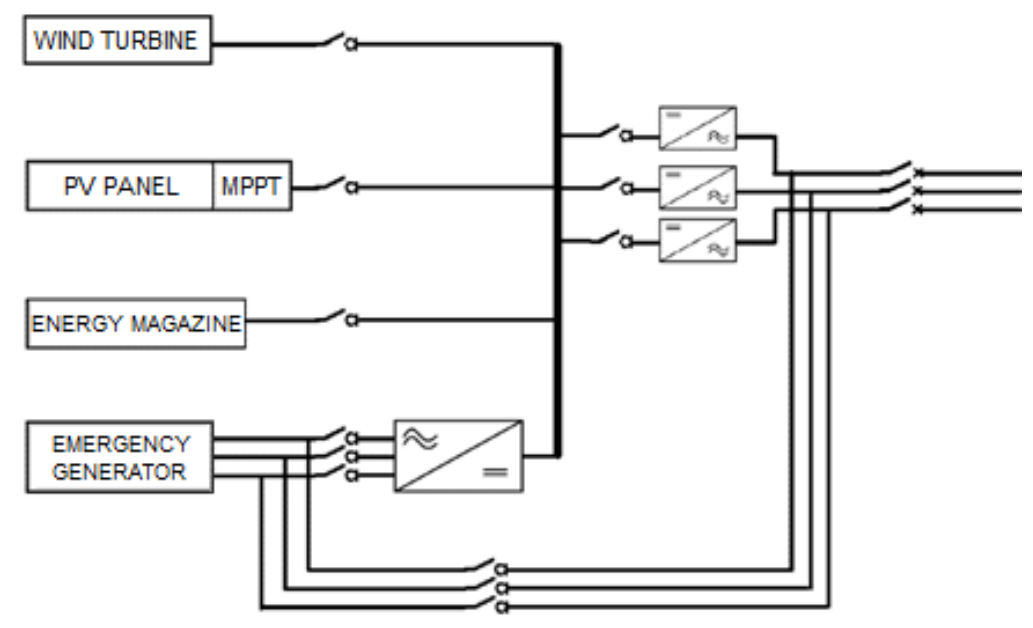

Fig. 2.1. Block diagram of energy source connections.

\section{Application design in the SCADA system}

\subsection{Design assumptions}

The SCADA system, for the needs of the project has been implemented in the Vijeo Citect environment [18]. Its task was to support the user and the installation which uses renewable energy sources in powering receivers in a household. The basic function of the system is to adjust the power consumption by circuits and devices in a single-family house to the generative capacities of energy sources and to the amount of energy collected in the battery. The assumption of the project was the autonomous operation of the object without the necessity of intervention of the operator during the undisturbed operation of the installation, with a possibility to control the system by the user with relevant authorisations.

The SCADA system communicates with the PLC by means of the MODBUS protocol. The controller performs orders regarding the connection of contactors, which are transmitted from the master system, and collects the information about the state of the installation. The production of electricity in energy sources, the battery charge and the fuel level in the diesel generator, the electricity flow to and from the energy storage, voltages of DC and AC circuits, power consumed by the equipment connected to the installation, states of overcurrent switches are all subject to measurements. Contactors which disconnect energy sources and inverters from the installation, converters which connect the emergency generator circuits and contactors which operate the power supply circuits of sockets, lighting and selected household equipment are subject to control.

\subsection{Controlling the distribution of energy}

Devices used at home are divided into groups assigned with power supply levels which determine the sequence of their deactivation in the event of a reduction in the battery charge and the necessity to improve the power balance. The criterion for the assignment of a given device to a specific group was its impact on the life of the household members and the effect which its long-lasting deactivation might have on them. 


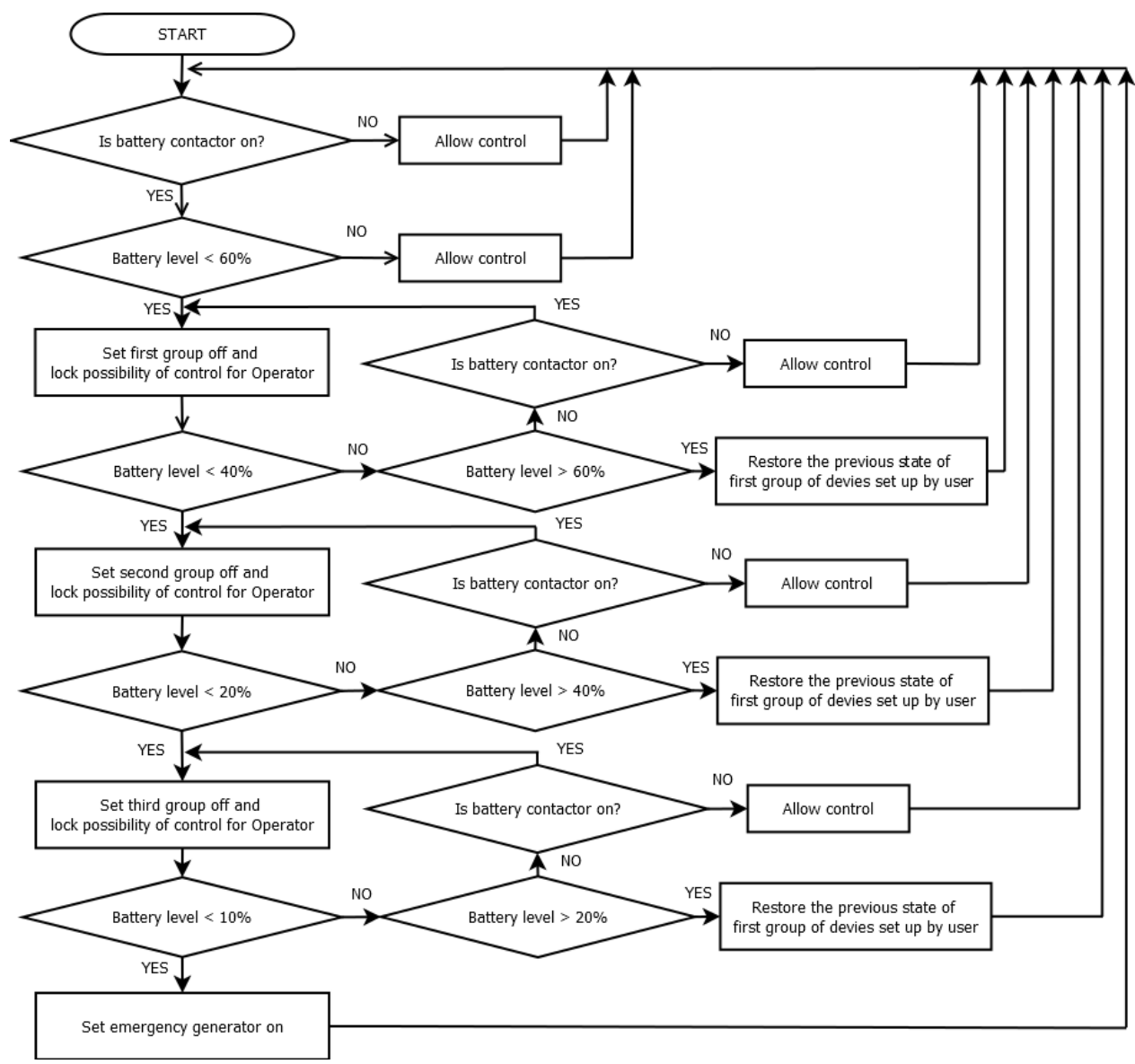

Fig. 3.1. Diagram of the algorithm for the energy distribution control.

The first power supply level occurs, when the battery is charged above $60 \%$, and it allows for the powering of all branch circuits. The first group of devices is switched off, when the amount of energy collected in the battery falls below $60 \%$. They include: a dishwasher, a TV set a microwave oven. The third power supply level is activated when the battery level falls below $40 \%$, which will cause the electric oven, the washing machine and the circuits of electrical sockets to be switched off. Another group of devices will be switched off, when the battery charge falls below $20 \%$ and it includes: computers in two bedrooms and part of the lighting. If the amount of energy collected in the battery falls below $10 \%$, the system will activate the fifth power supply level, which will cause the emergency generator to be switched on automatically. If the battery charge increases, causing the switching of the system to a lower battery charge, the circuits will return to the state before they were switched off. The refrigerator, the computer in bedroom No. 3, which operates the SCADA system, and the lighting in this bedroom and in the corridor have the highest priority and are not switched off automatically by the master system. The disconnection of the battery from the installation will cause the system to be operated in the first power supply level mode. Commands sent by the user with the Administrator's authorisations take precedence over the energy consumption control algorithm. The diagram of the algorithm is presented in Fig. 3.1. 


\subsection{Visualization of energy sources and receivers}

One of the most important functions of the SCADA system is the visualisation of the state of the object which it controls. In this project, the said function was implemented by means of the so called synoptic images (pages), which present the states of the parts of the installation responsible for the electricity production (Fig. 3.2), including the details regarding the respective energy sources (Fig. 3.3), and the receiver part (Fig. 3.4).

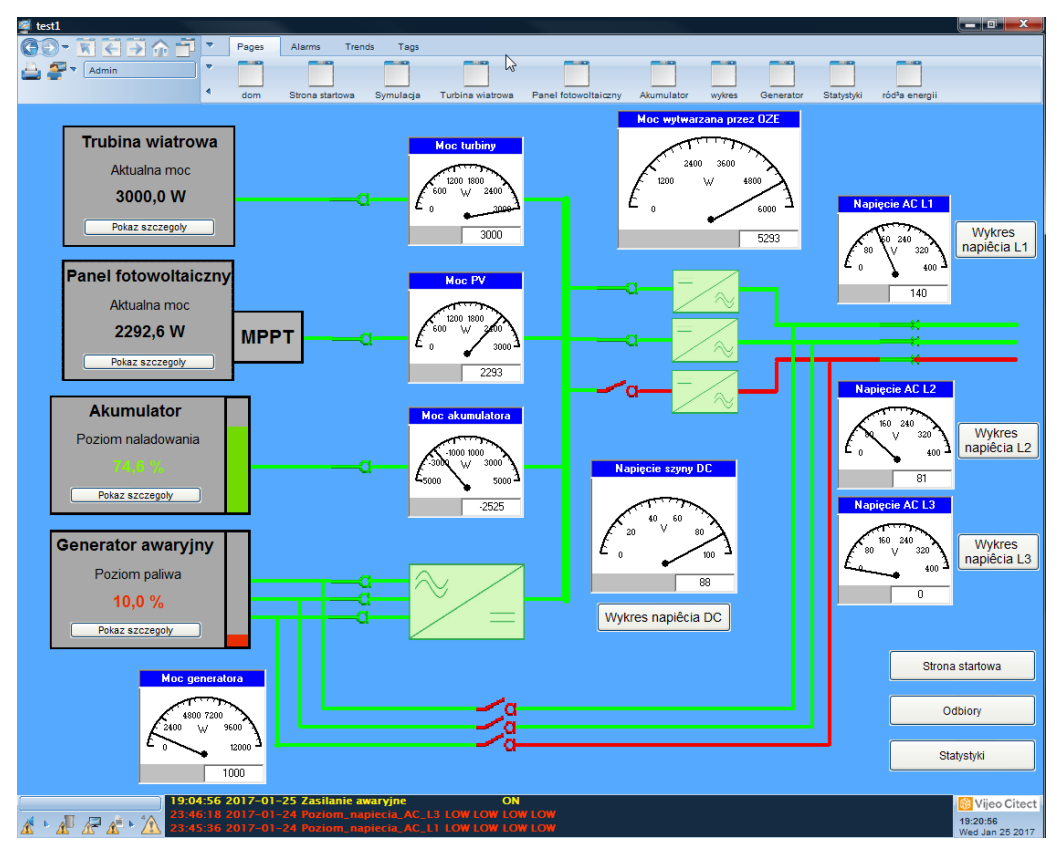

Fig. 3.2. Visualisation of energy sources (in Polish).

On each of the pages the user gains access to the information and the possibility of control in accordance with the possessed authorisations. From the level of the pages, it is possible to control connectors and switch on the emergency generator. The user also gains access to the data regarding the current state of the energy sources, circuits and equipment, as well as the archival data in the form of charts which represent the consumption or production of power and energy in time. 


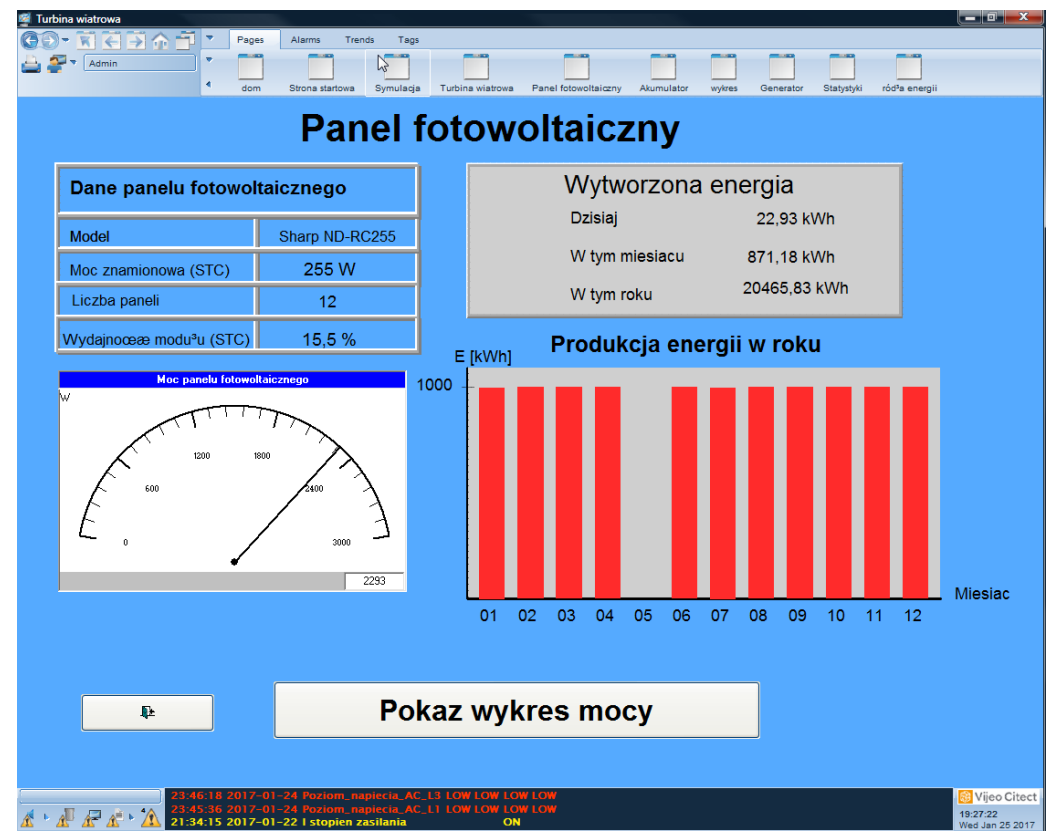

Fig. 3.3. Information about the energy source (in Polish).

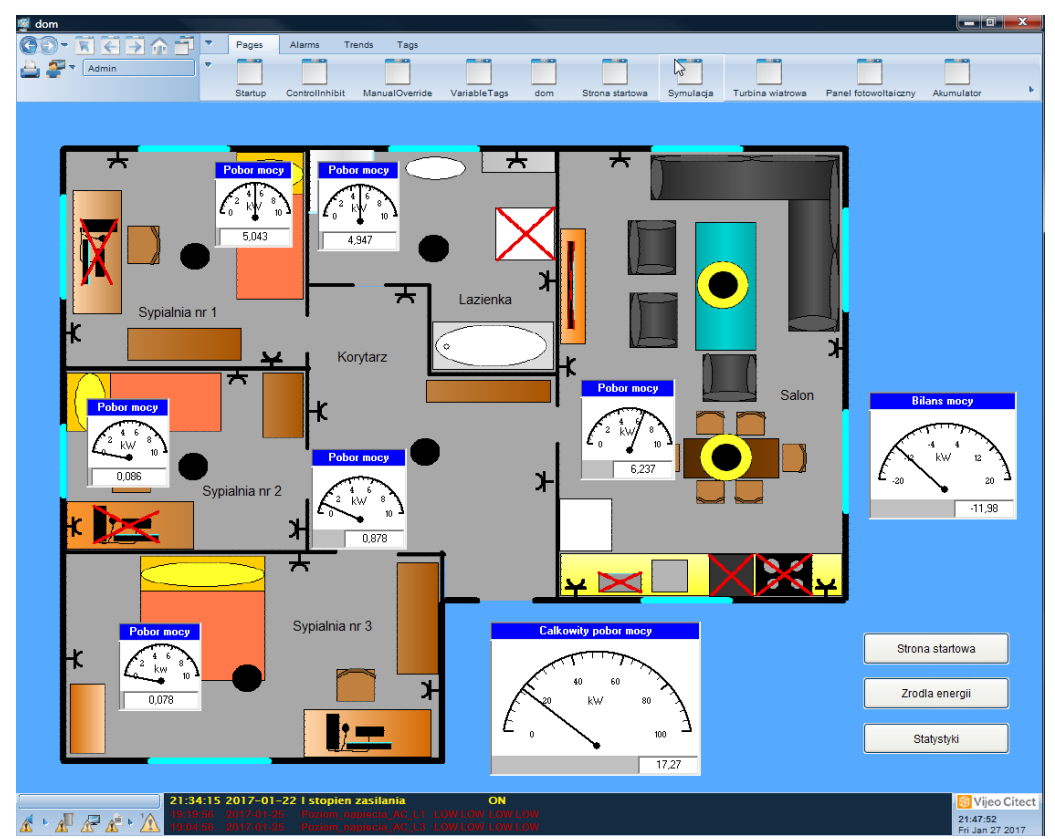

Fig. 3.4. Visualisation of the receiver part (in Polish).

\subsection{Alarms}

A very important task of the SCADA systems is to display alarms and inform the operator about any disturbances occurring during the operation of the object. In the project 
implemented in the Vijeo Citect environment, the alarms and warnings are displayed at the bottom of the screen.

The created system provides information about the activation of the power supply levels, failures of the rectifier, inverters, activation of the emergency generator, low fuel level and deviation of voltages from the rated values. The occurrence of alarms, except the display of a message, may result in the calling of the functions defined by the user. The occurrence of the alarms related to the power supply levels is responsible for the execution of the energy distribution control algorithm. Additionally the occurrence of the alarm signalling the inverter failure or the opening of the contactors which disconnect them, causes the emergency generator to be switched on, while the receivers are powered with the omission of the DC busbar. The disconnection of the energy storage also results in the activation of the generator and the contactor that provides power supply to the rectifier.

\subsection{Other important functionalities}

SCADA systems also cover the data analysis and archiving. In this project, all the user activities were saved into log files. The application also generates reports on the levels of energy generation by the respective sources, as well as on the consumption of electricity by the receivers on a daily and monthly basis.

The access control based on three user groups was also implemented in the system. Relevant authorisations were awarded to the aforementioned user groups, which include: Administrators, Operators and Guests. The Administrators are authorised to use all the system functionalities, the Operators have access to all the information, but have restricted control capability resulting from the object control algorithm. The Guests can only access some of the information.

\subsection{Implementation in the real object}

The Vijeo Citect environment allows for the creation, testing and simulation of the SCADA system based on the virtual PLC. The software implementation in the real object or installation, after the successful test phase is very simple and consists in the switching of the PLC configured in the system from the virtual operation mode to the real operation mode. The environment is provided with an integrated controller for communication via the MODBUS protocol, which is used by the PLC used in the project. Owing to this, it is possible to implement the created system in the real installation.

It is worth mentioning that each of the functionalities described in the paper (operation of controllers, alarms, trends, reports, etc.) may be handled by different working stations (servers) or using the parallel processing $[1,21]$, which allows for an increase in the performance of the given SCADA system. Furthermore, as well as the visualization and archiving of operating parameters of the given installation, the SCADA system may be used to monitor the current state of e.g. PV cells which constitute part of the panels or photovoltaic roof tiles $[23,25,26]$.

\section{Conclusion}

The developed concept of the autonomous RES installation and the SCADA system which supervises its operation may successfully serve the purpose of creation of a real object. The installation allows for the electricity supply to a single-family house without connection to the power grid. Despite large financial outlays to create the installation, it may be 
implemented in objects which cannot be connected to the grid or whose connection is difficult and costly.

The project ensures the maximum use of energy sources via control of energy consumption by devices used in a typical household. The use of the SCADA application for the object control offers great opportunities for the development and modification of the system and the demand control algorithm, which allows for the flexible adaptation to the needs of the object and the customer. Additionally, analysis of data coming from the system will allow for the optimisation of investment and operational costs of these types of installations. The implemented SCADA system may also be successfully applied in other hybrid power supply systems and in on-grid installations.

\section{References}

1. R. Jakuszewski, Programowanie Systemów SCADA, Wydawnictwo Pracowni Komputerowej Jacka Skalmierskiego (2008)

2. SCADA PRO-200 Podręcznik użytkowania, Zakład Elementów i Systemów Automatyki Przemysłowej MikroB, Ostrzeszów (2005)

3. http://systemy-sterowania.pl/informatyka-przemyslowa/ Informatyka przemysłowa, Systemy-sterowania.pl, date: 13.12.2016

4. http://www.utrzymanieruchu.pl/menu-gorne/artykul/article/systemy-scada-wsterowaniu-procesami-technologicznymi/, Systemy SCADA w sterowaniu procesami technologicznymi, Trade Media International, date: 10.12.2016

5. http://kompaniasolarna.pl/fotowoltaika/net-metering-na-czym-polega/, Net metering na czym polega, Kompania Solarna, date: 15.12 .2016

6. http://green-power.com.pl/pl/home/wiatr-i-jego-pomiar-w-energetyce-wiatrowej/, Wiatr i jego pomiar w energetyce wiatrowej, Green Power Development, date: 14.12.2016

7. Główny Urząd Statystyczny, Zużycie energii w gospodarstwach domowych w 2012 r., Główny Urząd Statystyczny, Warszawa (2014)

8. R. Tyrko, Małe elektrownie wiatrowe (MEW), Czysta energia, Wydawnictwo Abrys, $2(2010)$

9. http://www.rms.com.pl/oferta/turbiny-i-silownie-wiatrowe/turbiny-wiatrowe-opionowej-osi-obrotu/, Turbiny wiatrowe o pionowej osi obrotu, RMS POLSKA, date: 14.12.2016

10. W. Lewandowski, Proekologiczne odnawialne źródła energii, Wydawnictwo WNT, Warszawa (2012)

11. http://irena.masdar.ac.ae/?\&tool=dtu:gwa\&map=103, Global Wind Atlas, DTU WIND ENERGY, 13.12.2016

12. http://ekopulsar.pl/\#!/news/panele-fotowoltaiczne-porownanie, Porównanie paneli fotowoltaicznych, EkoPulsar, 15.12.2016

13. http://pro-sun.pl/?p=438, Kąt nachylenia instalacji fotowoltaicznej, WordPress, date: 24.01.2017

14. http://www.eco-energia.pl/index.php/14-baza-wiedzy/18-energia-slonca, Energia słońca, eco-energia.pl, date: 16.12.2016

15. http://wysokienapiecie.pl/sieci/1254-brakujace-ogniwo-energetyki, Brakujące ogniwo energetyki, WysokieNapięcie.pl, date: 18.12.2016

16. http://ep.com.pl/artykuly/10299-Akumulatory_litowe.html, Akumulatory litowe, AVT Korporacja, date: 18.12 .2016

17. G. Jarek, M. Jeleń, J. Michalak., M. Zygmanowski, Sterowanie przekształtnikiem AC/DC w interfejsie energoelektorniczymi dla mikroinstalacji prosumenckiej, Maszyny Elektryczne - Zeszyty Problemowe, Politechnika Śląska, 2, 110 (2016) 
18. http://www.schneider-electric.pl/pl/product-range/1500-vijeo-citect/?filter=business-1automatyka-przemys-owa-i-sterowanie\&parent-category-id $=5100, \quad$ Vijeo Ciect, SchneiderElectric, date: 25.01 .2016

19. K. Bednarek, Electrodynamic calculations and optimal designing of heavy-current lines, Prz. Elektrotechniczny, 84(12), 138 (2008)

20. K. Bednarek., J. Jajczyk, Effectiveness of optimization methods in heavy-current equipment designing, Prz. Elektrotechniczny, 85(12), 29 (2009)

21. L. Kasprzyk, Analysis of a light field with the use of parallel computers, Prz. Elektrotechniczny, 83(12), 128 (2007)

22. D. Burzyński, L. Kasprzyk, Modelling and simulation of lead-acid battery pack powering electric vehicle, E3S Web of Conferences, 14, Vol. 01041 (2017)

23. D. Kurz, Computational Problems of Electr. Eng., 1-5 (IEEE Xplore, Sandomierz, 2016) (DOI: 10.1109/CPEE.2016.7738739)

24. J. Jajczyk, A. Dobrzycki, M. Filipiak, D. Kurz, International Conference EEMS Energy, Environment and Material Systems, (EEMS, E3S Web of Conferences 19, 01027, 2017) (https://doi.org/10.1051/e3sconf/20171901027)

25. K. Skowronek, G. Trzmiel, The method for identification of fotocell in real time, Prz. Elektrotechniczny, 83(11), 108 (2007)

26. G. Trzmiel, Eksploatacja i Niezawodnosc - Maintenance and Reliability, 19/4, 516 (2017) (http://dx.doi.org/10.17531/ein.2017.4.4) 